\title{
Geographical assessment of urban utilities in Pune Municipal Corporation region with changing urban population
}

\author{
V. Nagarale \\ Shreemati Nathibai Damodar Thackersey Women's University \\ Maharshi Karve Vidyavihar, Karve Road, Pune 411038, India
}

\begin{abstract}
The rapid growth of urban area and extraordinary population growth are the most dramatic phenomenon associated with urbanization. This rapid and haphazard growth of urban sprawl and increasing population pressure results in the various adverse effects on urban environment. In India major metropolitan cities are already saturated due to large scale immigration of population. Urban centres and Metropolitan cities are growing haphazardly in all directions without proper planning. Pune is the eighth largest city in India in terms of both population and GDP driven by rapid urbanization. Pune's population will grow up from 5.5 million to 7.7 million by 2030 and it will create severe strain on core urban infrastructure. Pune city lies between $18^{\circ} 25^{\prime}$ to $18^{\circ} 37^{\prime}$ North latitude and $73^{\circ} 44^{\prime}$ to $73^{\circ} 57^{\prime}$ East longitude. The study area covers $243.84 \mathrm{~km}^{2}$ composed of 144 general electoral wards. According to 2011 which comes under 14 administrative wards of Pune Municipal Corporation with population with 3.12 million Pune city in India is growing at a very fast rate.

In the present study population changes with utility services are considered for sustainable urban environment. In Pune Municipal Corporation each ward's population it is found that uneven distribution of various utility services which leads various problems in management and planning of Pune Municipal Corporation. For present study e-Suvidha centres and 24 hours open medical stores are considered. In PMC 88 e-Suvidha centres and 124 medical stores which are day and night are available. Hadapsar administrative ward has maximum number of population in PMC. In 2011, this ward has 3240751 populations. This ward has $16 \%$ Maha e-Suvidha centres, $12 \%$ medical stores which are 24 hours open. When these available utilities are compare with wards total population it is notice that the ratio of number of population and available utility services are not properly distributed with various geographical parameters.
\end{abstract}

Keywords: urbanization, utility services, PMC, GDP

\section{Introduction}

Present research paper deals with urban utilities in urban area and how the changing population effects on distribution of utility services. Municipal Corporation is one of the urban body who deals with urban planning and administration of particular area.

Urbanization is broadly defined as a growth of towns and increasing ratio of rural to urban population of a country. The sheer magnitude of the urban population, haphazard and unplanned growth of urban areas and a desperate lack of infrastructure are the main causes of such a situation. The rapid growth of urban population both natural and through migration has put heavy pressure on public utilities like housing, sanitation, transport, water, electricity, education, health and so on. 
Utility services itself explain the services which we are utilizing for the wellbeing of human population. Urban area is differing from rural area because of its service providing nature. Good transportation system, electricity, water supply, proper urban land use, education, recreation, health and sanitation, etc. Standard or quality of city has been determined by the status of these services. The maximum satisfaction from consuming goods or services is also considered as utility service. Utilization of something, in practical sense its use.

\section{Literature review}

Deshpande C.D. (1975) has observed this process in India in the form of ribbon development along the main roads, railway lines and beaches, planned rail-linked suburbs and their expansion, working class migrations to industrial centers, shanty towns and strip slums.

Sokhi and Rashid (1999) studied the landuse and landcover mapping in urban areas using aerial photographs and satellite imageries of Jaipur (1983 \& 1989), Coimbatore (1984), Ujjain (1985), Delhi (1987), Dehradun (1989), Bangalore (1994) and Jammu (1995), on the basis of urban sprawl analysis of these cities they concluded that human settlements are tend to expand in all directions of favourable conditions.

Prasad et al. (2001) worked on urban sprawl for Hyderabad city and its environs. $\mathrm{He}$ applied Shannon's entropy approach to measure the degree of spatial concentration of geographical variables and demonstrated the utility of entropy approach to identify, measure and monitor spatio-temporal patterns of urban sprawl.

Shekhar Sulochana (2005) emphasized the significance of remote sensing as source of information and GIS as powerful technologies for analyzing spatial and non-spatial data in urban sprawl of Pune city.

Datta Pranati (2006) worked on Indian urbanization, and number of population residing in urban areas has increased from 2.58 crores in 1991 to 28.53 crores in 2001. India is one among the country of low level of urbanization. In 2001, 306.9 million Indians were living in nearly 3700 towns and cities spread across the country, and it is expected to increase to over 533 million by 2021 respectively. In India, urbanization has been relatively slow compared to many developing countries. Only $28 \%$ of population was living in urban areas as per 2001 census.

Bhailume S. (2011) worked on 'An Assessment of Urban Sprawl using GIS and Remote Sensing Technique; A Case Study of Pune-Pimpri-Chinchwad Area'. He emphasised on how RS-GIS techniques can be helpful to find out urban sprawl in Pune and PimpriChinchwad Area.

Anushree Kadam (2014) worked on urban sprawl and urban utility services in the Pimpri-Chinchwad Municipal Corporation (PCMC). In her research she highlights on urban land use changes among four administrative regions with some basic utility services.

\section{Study Area}

Pune is the eighth largest city in India in terms of both population and GDP driven by rapid urbanization. Pune's population will grow up from 5.5 million to 7.7 million by 
2030 and it will create severe strain on core urban infrastructure. Previous to 1950, the Pune city Municipality and Pune Suburban Municipality governed the city of Pune. Since the population of the both these Municipalities reached a considerable number, the State Government constituted the Pune Municipal Corporation (PMC) on $15^{\text {th }}$ February 1950. The Bombay Provincial Municipal Corporations Act, 1949, governs it. Now, the administrative wing of PMC is divided into 14 administrative wards and those wards are maintaining some prime functional departments. Pune Municipal Corporation is located in Pune District in western region in Maharashtra state between $17^{\circ} 50^{\prime}$ North to $19^{\circ} 24^{\prime}$ North latitude and $73^{\circ} 19^{\prime}$ East to $75^{\circ} 10^{\prime}$ East longitudes. The city is located to the South-East of Mumbai at an elevation of $560 \mathrm{~m}$ above mean sea level. The total area of PMC is $243.96 \mathrm{~km}^{2}$. When the Pune Municipal Corporation set up in 1951 it catered to a total population of 4.85 lakhs. The main reasons for a significant change in the population size from 1920 to 1950 were increase in employment and business opportunities after the World War II, large-scale migration from Pakistan after partition and from other neighboring countries.

Total population of PMC is increases from 1951 to 2011, in 1951 it was 488,419 and in next six decades it is observed that the population increases in every decade. In 2011, total population of PMC is 3124 458. From 1951 to 2011 various changes are occur in PMC and this quick changes plays vital role to make over the cities old identity 'Pensioners Pune' to 'IT Pune'.

\section{Methodology}

The present work covers Pune Municipal Corporation area in Maharashtra India. The methodology adopted for the present study is divided into pre-field interpretation, preliminary interpretation and post-field verification and interpretation of data phases.

Library work includes exhaustive literature survey of the topic of investigation has been undertaken. Published literature, reports also collected from various libraries, institutes; Government Departments, etc. Pre-field phaseincludes collection of different maps, Satellite imageries and topographical maps. Collection of non-spatial data, utility services data details will be obtained from PMC. Fieldphases included various visit to the study area and its fringe areas in different seasons, GPS surveys, instrumental surveys, photographs, questionnaire surveys, etc. Laboratory work includes the digitization of various layers, preparation of maps and other GIS/RS techniques. i.e., georeferencing, digitization, attribution, data attachment, overlay analysis, supervised and unsupervised classification, final layouts of different maps.

\section{Data Collection}

The data required for the present study is as follows.

\begin{tabular}{|l|l|l|}
\hline Segment & \multicolumn{1}{|c|}{ Type of Data } & \multicolumn{1}{|c|}{ Source } \\
\hline \multirow{2}{*}{$\begin{array}{l}\text { Spatial } \\
\text { data }\end{array}$} & SOI Toposheets - scale 1:25000, 1:50000 & Survey of India \\
\cline { 2 - 3 } & Satellite data for different periods & National Remote Sensing Centre, Hyderabad (NRSC) \\
\hline \multirow{2}{*}{$\begin{array}{l}\text { Non-spatial } \\
\text { data }\end{array}$} & Utility services from various wards & Pune Municipal Corporation (PMC) \\
\cline { 2 - 3 } & Ward wise population data & PMC and Census 2001 \& 2011 and later \\
\cline { 2 - 3 } & Ward wise questionnaire & Information by Field Investigation \\
\hline
\end{tabular}




\section{Data Analysis}

Data analysis will be carried out in following wanner.

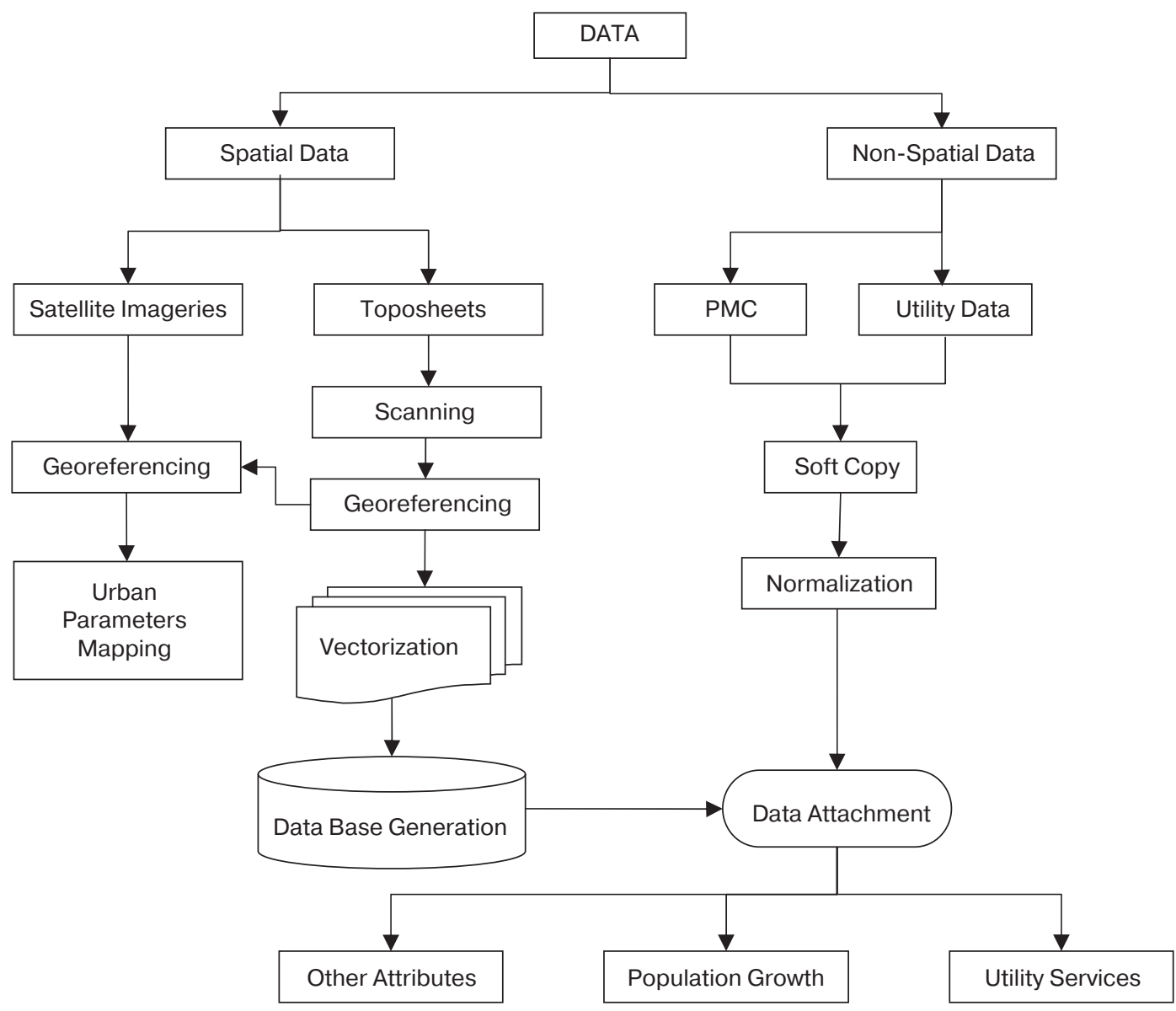

Flowchart of Methodology

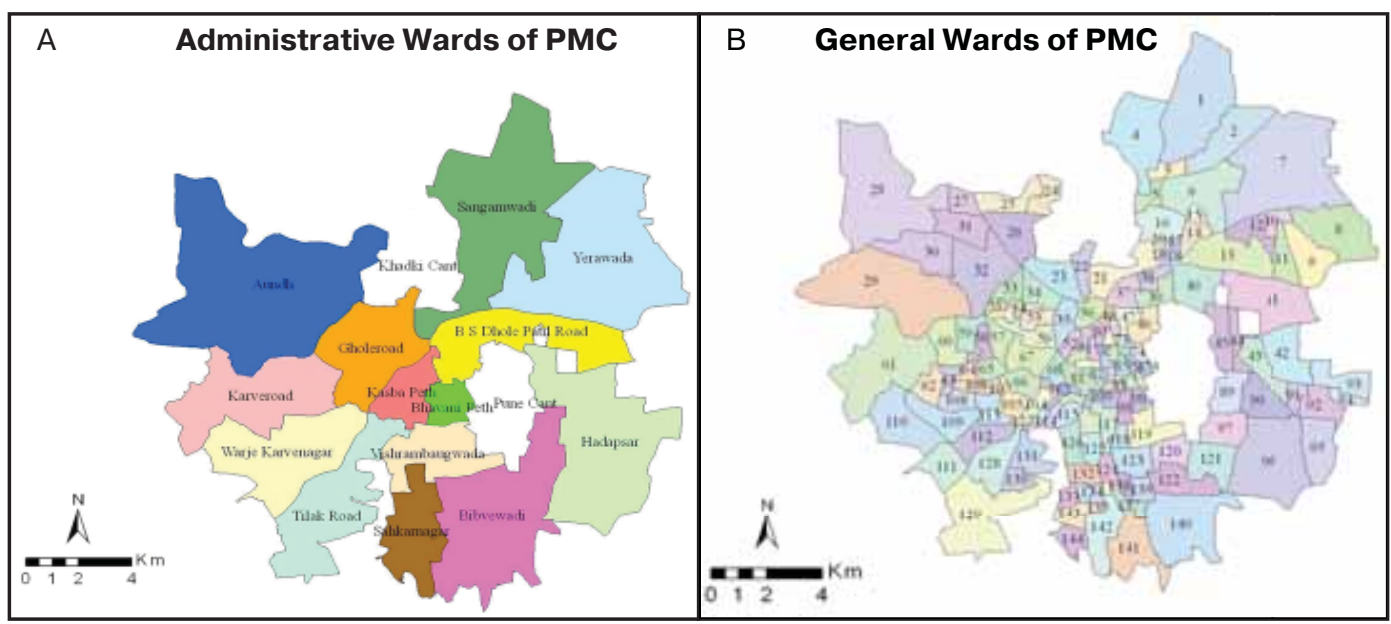

Figure 1. Location of Study Area 
Population of PMC

\begin{tabular}{|c|l|c|c|c|c|c|c|}
\hline Sr. No & Ward name & $\begin{array}{c}\text { Total } \\
\text { Geographical } \\
\text { Area km } \text { km }^{2}\end{array}$ & $\begin{array}{c}\text { TGA } \\
\text { in } \%\end{array}$ & $\begin{array}{c}\text { Population, } \\
2001\end{array}$ & $\begin{array}{c}\text { Population, } \\
2011\end{array}$ & $\begin{array}{c}\text { Population } \\
\text { District (\%) } \\
2001\end{array}$ & $\begin{array}{c}\text { Population } \\
\text { District (\%) } \\
2011\end{array}$ \\
\hline 1 & Aundh & 40.75 & 16.17 & 175755 & 181124 & 7.4 & 5.8 \\
\hline 2 & B.S. Dhole Patil & 14.64 & 6 & 154919 & 155413 & 6.53 & 4.97 \\
\hline 3 & Bhavani Peth & 2.9 & 1.18 & 160504 & 192932 & 6.76 & 6.17 \\
\hline 4 & Bibvewadi & 18.35 & 7.52 & 174811 & 291446 & 7.36 & 9.33 \\
\hline 5 & Dhankawadi & 10.84 & 4.44 & 151692 & 236648 & 6.39 & 7.57 \\
\hline 6 & Ghole Road & 12.76 & 5.23 & 198286 & 171678 & 8.35 & 5.49 \\
\hline 7 & Hadapsar & 24.78 & 10.15 & 123288 & 324751 & 5.19 & 10.39 \\
\hline 8 & Karve Road & 16.26 & 6.66 & 171632 & 209331 & 7.23 & 6.7 \\
\hline 9 & Kasba Vishrambagh & 5 & 2.04 & 211388 & 178484 & 8.9 & 5.71 \\
\hline 10 & Sahakarnagar & 9.2 & 3.77 & 166902 & 205441 & 7.03 & 6.58 \\
\hline 11 & Sangamwadi & 29.44 & 12.06 & 166364 & 261957 & 7.01 & 8.38 \\
\hline 12 & Tilak Road & 14.71 & 6.02 & 175112 & 242290 & 7.38 & 7.75 \\
\hline 13 & Warje Karvenagar & 15.23 & 6.24 & 140250 & 233399 & 5.91 & 7.47 \\
\hline 14 & Yerawada & 29.1 & 11.92 & 203110 & 239564 & 8.56 & 7.67 \\
\hline Total & & $\mathbf{2 4 3 . 9 6}$ & & $\mathbf{2 3 7 4 0 1 3}$ & $\mathbf{3 1 2 4 4 5 8}$ & & \\
\hline
\end{tabular}

Source: Census of India and PMC.

\section{Results}

In the present study three urban services namely Property Tax collection, e-Suvidha and Blood distribution has been considered. Administrative ward wise population and number of services has been shown in the tables and maps as below.

Table 2

Property-Tax Pay Offices in PMC

\begin{tabular}{|c|l|c|c|c|}
\hline Sr. No & \multicolumn{1}{|c|}{ Ward name } & Area in $\mathrm{km}^{2}$ & Population, 2011 & Tax Pay Office \\
\hline 1 & Aundh & 40.75 & 181124 & 6 \\
\hline 2 & B.S. Dhole Patil & 14.64 & 155413 & 3 \\
\hline 3 & Bhavani Peth & 2.90 & 192932 & 4 \\
\hline 4 & Bibvewadi & 18.35 & 291446 & 5 \\
\hline 5 & Dhankawadi & 10.84 & 236648 & 4 \\
\hline 6 & Ghole Road & 12.76 & 171678 & 5 \\
\hline 7 & Hadapsar & 24.78 & 324751 & 4 \\
\hline 8 & Karve Road & 16.26 & 209331 & 2 \\
\hline 9 & Kasba Vishrambagh & 5.00 & 178484 & 5 \\
\hline 10 & Sahakarnagar & 9.20 & 205441 & 4 \\
\hline 11 & Sangamwadi & 29.44 & 261957 & 2 \\
\hline 12 & Tilak Road & 14.71 & 242290 & 4 \\
\hline 13 & Warje Karvenagar & 15.23 & 233399 & 65 \\
\hline 14 & Yerawada & 29.10 & 239564 & 5 \\
\hline Total & & 243.96 & 3124458 & \\
\hline
\end{tabular}

Source: Census of India, PMC and field visits. 


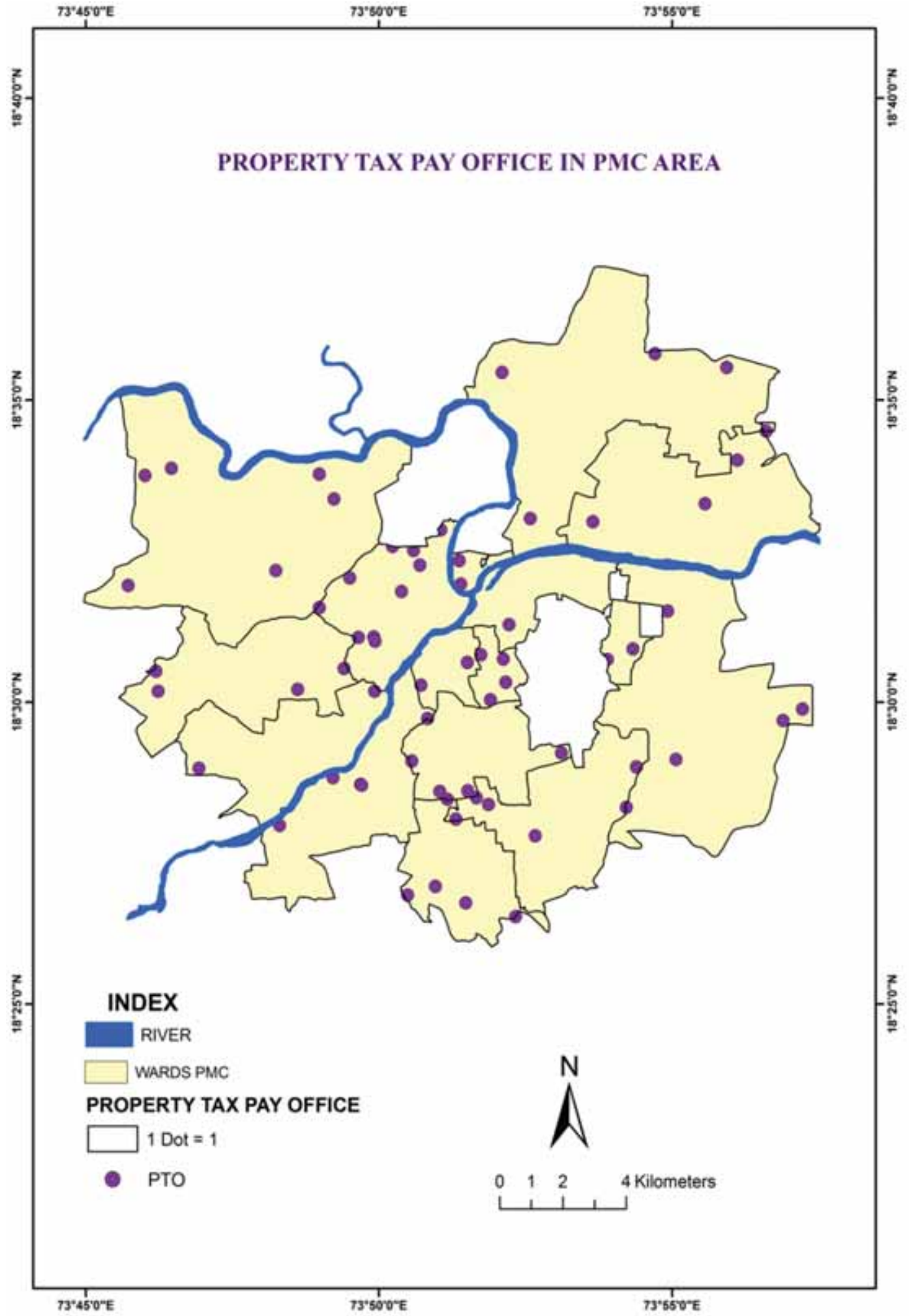

Figure 2. Maha e-Suvidha Center in PMC 
Table 2 and figure 2 shows the ward wise numbers of Property Tax Pay Office in Pune Municipal Corporation. Property Tax collection is revenue collection, which is one of the main source that helps to allocate various budget allocation in next financial year. Property Tax is pay for one time overall the year. Online pay mode is also available to people, but minimum numbers of people has knowledge about the online transaction. Most of people directly go to the Property Tax Pay Office to pay the tax amount. Due to minimum numbers of those offices, peoples face inconvenience in those days. Hence, to take out from this inconvenience, there is need to focused on number of Property Tax Pay Office. Ghole Road administrative ward has maximum numbers of Property Tax Pay Office. As compare with other 13 administrative wards, Ghole Road ward has maximum number of government offices like Pune Municipal Corporation Main Building, Akashvani, Shivajinagar Court, as well as Sambhaji Udyan, British Library, International Convention Center, Agriculture College. Due to this influence, this ward has maximum Property Tax Pay Office, i.e. 12. Total population of this ward as on 2011 is 171678 , hence the number of Property Tax Pay Offices is not sufficient but agreeable. Kasba Vishrambagh and Warje Karvenagar this administrative ward has only two Property Tax Pay Offices. Kasba Vishrambagh ward has total population as on 2011 is 178484 and Warje Karvenagar ward has total population as on 2011 is 233 399, hence the number of Property Tax Pay Office is not enough in both of this ward.

Facilities with internet and various software attracts people to participate at their convenience time. In earlier period there was time restrictions as well as time consumption for such services. e-Suvidha is an e-governance package, designed for community information centers of states of India. This web-enabled software is developed to automate a number of citizen-centric services being delivered by the district/block administration. This brings in transparency to the process of providing services at the local level and reduces harassment of the citizens. These all centres are equipped with computer and communication infrastructure and allow the local population to get connected with the digital world. Government of Maharashtra has implemented a National e-Governance Plan (NeGP) to provide government services to the common people at their doorstep and at an affordable cost. With an aim to bring transparency in the system and establish citizen centric governance. Maha e-Suvidha provides a one-stop interface to citizen to interact with government departments. This center provides several internet/online enables facilities to the urban citizens under one roof.

Table 3 illustrates the ward wise numbers of e-Suvidha centers in Pune Municipal Corporation. This Maha e-Suvidha centers provide many governments recognize services like Pan Card, Reshan Card, Shop Act, Aadhar Card, Smart Card, Gazette, Income Certificate, Domical Certificate, Cast Certificates, Voter Id Card, Gap Certificate, all types of affidavits, Live and Death Certificate, Light Bill, Phone Bill, LIC premium, etc. In Pune Municipal Corporation Tilak Road and Hadapsar this two administrative wards have maximum numbers of Maha e-Suvidha centers. Tilak Road has $15 \mathrm{e}$-Suvidha centers where Hadapsar has 14 e-Suvidha centers. Hadapsar Administrative ward has largest population in PMC, i.e. 324751 , hence total population of this ward and the number of e-Suvidha centers ratio is agreeable level. Aundh, Bibvewadi and Sangamwadi this three administrative wards have minimum numbers of e-Suvidha centers, i.e. 3. In PMC, 
Bibvewadi administrative ward is known for the migrate people. Many people of this ward are migrate from various parts of Maharashtra and India. This ward has several activities related construction business, hence there is need of skill and non-skill people for those construction business. People from out of this area migrate here for job availability and low rent houses in slum area. Most of this people are illiterate and unknown about government facilities. Hence less demands of governmental documents from such peoples and local politician's ignorance Bibvewadi ward has only 3 e-Suvidha center.

Table 3

e-Suvidha Centers in PMC

\begin{tabular}{|c|l|c|c|c|}
\hline Sr. No & Ward name & Area in $\mathrm{km}^{2}$ & Population, 2011 & e-Suvidha Center \\
\hline 1 & Aundh & 40.75 & 181124 & 3 \\
\hline 2 & B.S. Dhole Patil & 14.64 & 155413 & 6 \\
\hline 3 & Bhavani Peth & 2.90 & 192932 & 5 \\
\hline 4 & Bibvewadi & 18.35 & 291446 & 6 \\
\hline 5 & Dhankawadi & 10.84 & 236648 & 6 \\
\hline 6 & Ghole Road & 12.76 & 171678 & 14 \\
\hline 7 & Hadapsar & 24.78 & 324751 & 4 \\
\hline 8 & Karve Road & 16.26 & 209331 & 7 \\
\hline 9 & Kasba Vishrambagh & 5.00 & 178484 & 3 \\
\hline 10 & Sahakarnagar & 9.20 & 205441 & 15 \\
\hline 11 & Sangamwadi & 29.44 & 261957 & 4 \\
\hline 12 & Tilak Road & 14.71 & 242290 & 7 \\
\hline 13 & Warje Karvenagar & 15.23 & 233399 & 88 \\
\hline 14 & Yerawada & 29.10 & 239564 & 243.96 \\
\hline Total & & 243.96 & & 5 \\
\hline
\end{tabular}

Source: Field work.

Blood is universally recognized as the most precious element that sustains life. It saves innumerable lives across the world in a variety of conditions. A blood bank is a place designed especially for the storage of blood and blood products. The term 'blood bank' typically refers to a division of a hospital laboratory where the storage of blood product occurs and where proper testing is performed to reduce the risk of transfusion related events. Blood bank accepts the donated blood. A person or a hospital can request the blood from the blood bank when they need. Seeker can get the desired blood group from blood bank (Kulkshreshtha Vikas et al., 2012). Pune city is well known for its medical facilities. Multispecialty Hospitals, 24 hour open hospitals, use of modern technologies in medical treatment, highly qualified and experienced medical staff this are the significance of medical facilities of PMC. Ambulance service, medical stores, surgical equipment providers, blood banks this services are directly involving in medical services. Blood banks are including in and as an emergency service. Most of the hospitals in the Pune city have their own blood bank. 


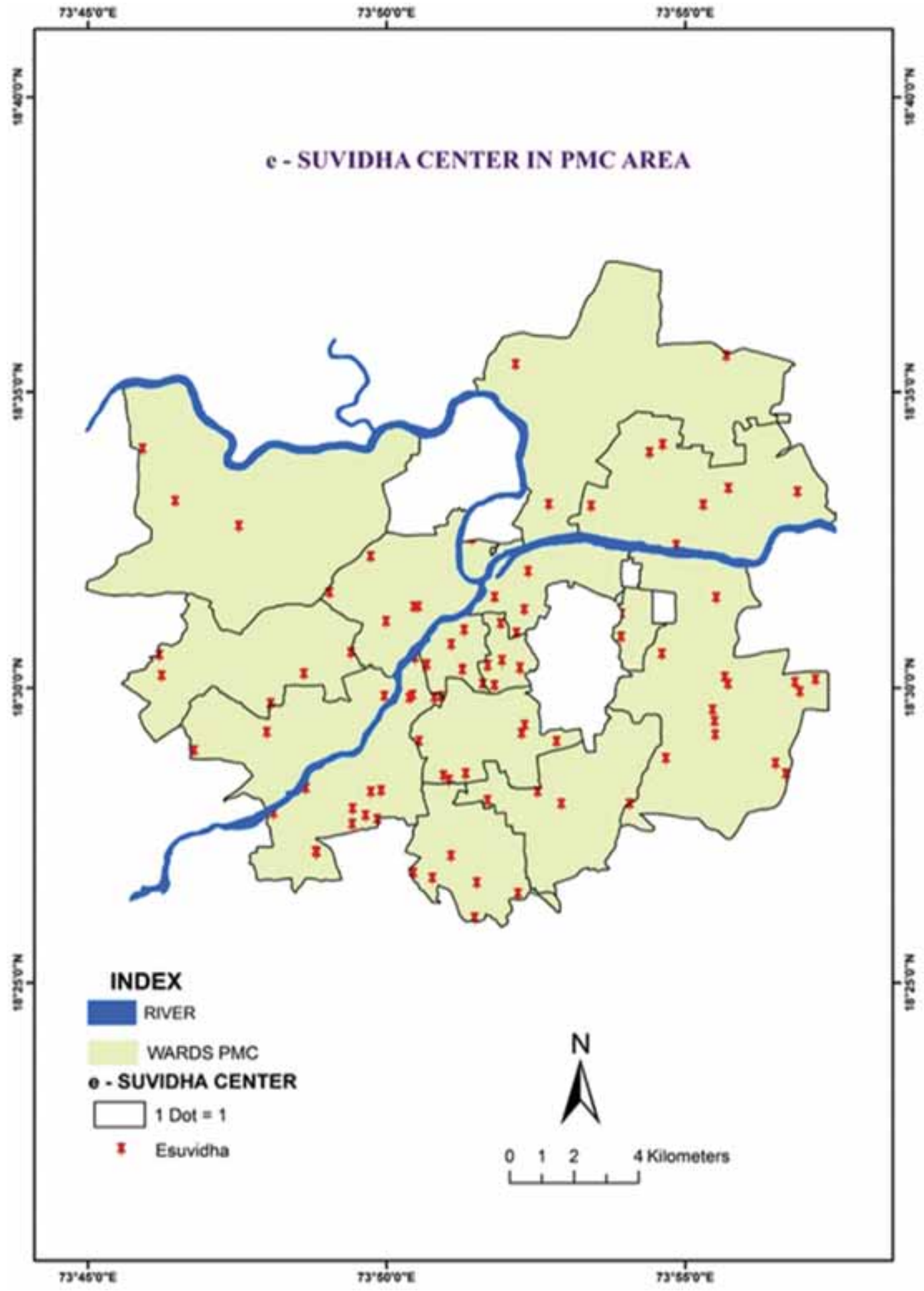

Figure 3. e-SUVIDHA center in PMC area 


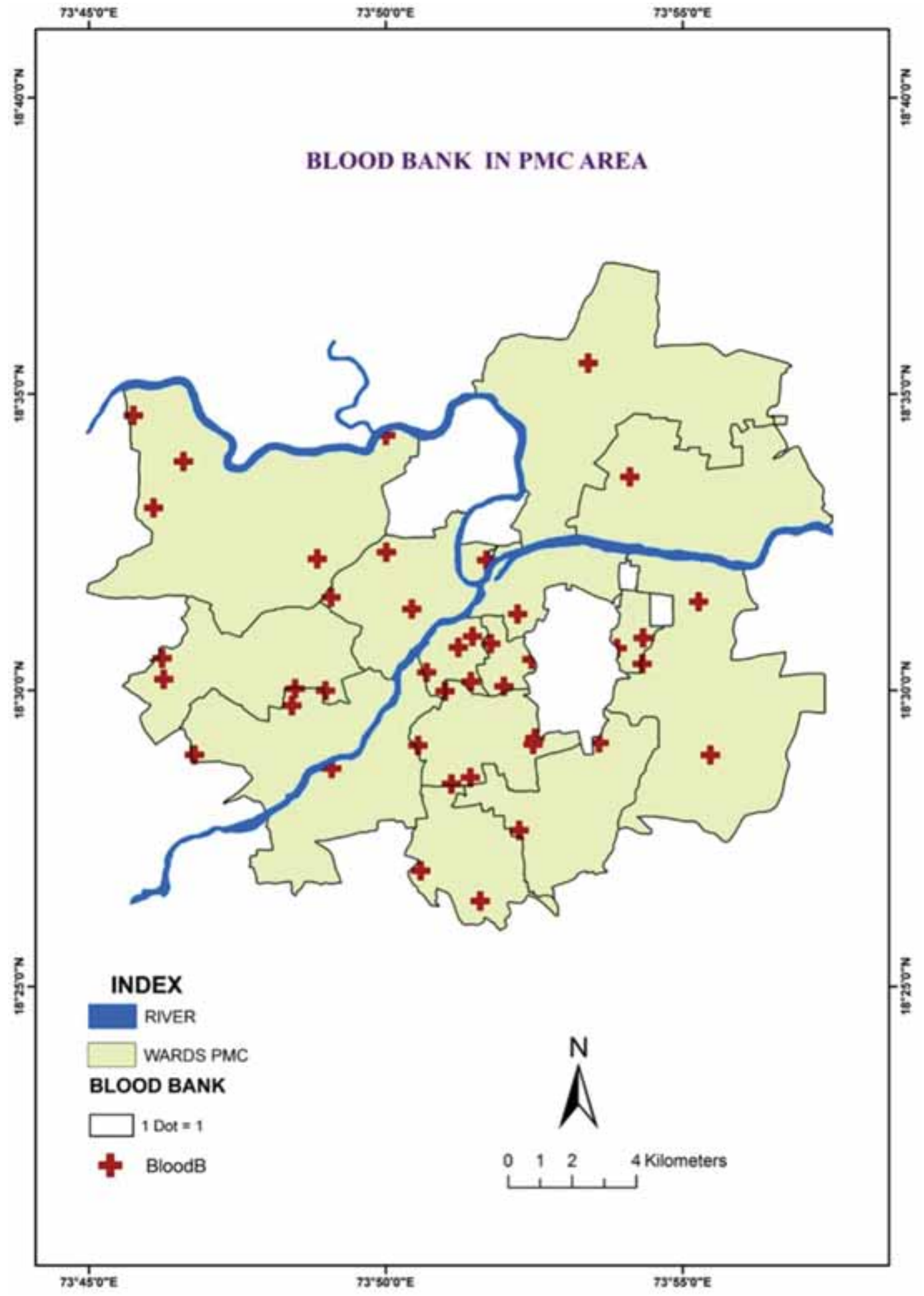

Figure 4. Blood bank in PMC area 
Blood banks in PMC

\begin{tabular}{|c|l|c|c|c|}
\hline Sr. No & \multicolumn{1}{|c|}{ Ward Name } & Area $\mathrm{km}^{2}$ & Population, 2011 & Blood Bank \\
\hline 1 & Aundh & 40.75 & 181124 & 5 \\
\hline 2 & B.S. Dhole Patil & 14.64 & 155413 & 3 \\
\hline 3 & Bhavani Peth & 2.90 & 192932 & 3 \\
\hline 4 & Bibvewadi & 18.35 & 291446 & 2 \\
\hline 5 & Dhankawadi & 10.84 & 236648 & 2 \\
\hline 6 & Ghole Road & 12.76 & 171678 & 4 \\
\hline 7 & Hadapsar & 24.78 & 324751 & 3 \\
\hline 8 & Karve Road & 16.26 & 209331 & 3 \\
\hline 9 & Kasba Vishrambagh & 5.00 & 178484 & 4 \\
\hline 10 & Sahakarnagar & 9.20 & 205441 & 1 \\
\hline 11 & Sangamwadi & 29.44 & 261957 & 1 \\
\hline 12 & Tilak Road & 14.71 & 242290 & 3 \\
\hline 13 & Warje Karvenagar & 15.23 & 233399 & 1 \\
\hline 14 & Yerawada & 29.10 & 239564 & 41 \\
\hline Total & & 243.96 & 3124458 & \\
\hline
\end{tabular}

Source: PMC and field work.

Table 4 reveals the ward wise numbers of blood bank in Pune Municipal Corporation. In PMC, Sahakarnagr ward has maximum numbers of blood bank, i.e. 6, where Sangamwadi, Tilak Road, Yerawada this ward has minimum number of blood bank, i.e. 1.

Multispecialty and big hospitals has their own blood bank. Jahangir Hospital, Ruby Hospital, K.E.M. Hospital, Dinanath Mangeshkar Hospital, Sahyadri Hospital, Shashvat Hospital, Ratna Memorial Hospital, Poona Hospital and Research Center, Navle Hospital, Tarachand Hospital, Sasoon Hospital this are the example of hospital who has their own blood bank. In PMC total number of blood bank is 41 . The number of total blood bank is look like minimum with compare to number of hospitals and patient, but those hospitals has their own blood bank they have sufficient stock of blood. Each hospital has well refrigeration containers system to hold blood products at a constant temperature and are dispersed wherever required. Nowadays people are aware of blood donation. Hospital registers the blood donor's information like name, blood group, contact. Hospital sends notification to the person regarding donation camp or emergency donation. These hospitals also have updated list of donors.

\section{Some major conclusions}

For the better administration and planning, it is essential to correlate various urban services with the present population and future population. Changing population in various metropolitans creates various problems and pressure on available resources. To overcome all the problems encountered in development process some of following conclusions can give pathway to planning administration.

Property tax is pay for one time overall the year. Online pay mode is also available to people, but minimum numbers of people has knowledge about the online transaction. 
Most of people directly go to the Property Tax Pay Office to pay the tax amount. Due to minimum numbers of those offices, peoples face inconvenience in those days. Hence, communicate with the people and help them to understand and use the online pay mode.

In PMC, 88 e-Suvidha centers are active. These e-Suvidha centers provide all governmental services like to issue smart card, domicile, etc. Most of the people are unknown about the services which are provide by the e-Suvidha centers. Hence it is need to arrange some program for people's awareness. The staff, which is appointed in e-Suvidha center, should be well knowledgeable, expert and well train to handle online and offline services. If people will use this centers, the difficulties are reducing to get the government documents and e-governance policy will be get success as well as achieve the transparency in every activity. Regional language facility or language translator should be there to attract more and more peoples.

Health care and health information is an integral part to everyone for sustainable livelihood. Multispecialty hospitals of PMC have their own blood bank. Nowadays hospitals update the list of blood downer, blood group and contact detail of the downer. Now e-blood banking system is useful and time consuming system. This system always updated with the name of blood bank, address and blood group availability. If hospital or even a patient visit to online this e-banking portal they get detailed information and they directly contact to those blood bank. National Health Portal of India is one of the example of e-blood banking. If all hospitals are interlinking with each other and use the benefit of e-blood banking that is very helpful to all hospital and patient too.

(C) Nagarale V., 2018

This work is licensed under a Creative Commons Attribution 4.0 International License

\section{References}

Bane R., Rawal A. (2003). GIS for land use patterns and land transformation - a case study of Anand City. Indian Cartographic.

Bhailume S. (2011). An Assessment of Urban Sprawl using GIS and remote sensing technique - a case study of Pune-Pimpri-Chinchwad Area' (PhD Thesis. Tilak Maharashtra Vidyapeeth, Pune).

Dash S., Ray D. (2005). e-Governance: case studies. Available at: www.csi-sigegov.org >casestudies

Datta P. (2006). Urbanization in India, regional and sub-regional population dynamic population process in urban areas, European Population Conference.

David B. and et al. (2006). The Property Tax: its role and significance in Funding state and local government services. George Washington Institute of Public Police (GWIPP), The George Washington University.

Deshpande C.D. (1971). Geography of Maharashtra. National Book Trust, New Delhi.

Epstein J., Payne K., Kramer E. (2001). Techniques for Mapping Suburban sprawl. Photogrammetric Engineering and Remote Sensing, 63(9), 913-918.

Erle E. (2010). Land-use and land-cover change. Climate Change. Available at: http://www.eoearth. org/article/Land-use

Jaykumar S., Arockiasamy J.J. (2003). Land use/land cover mapping and changes detection in part of Eastern Ghats of Tamil Nadu using remote sensing and GIS. Journal of the Indian Society of Remote Sensing, 31(4). 
Jha V.C., Hazar P.B. (1993). Land-use/land cover analysis of Deoghar Upland using remote sensing techniques. The Deccan Geographer, XXXI(1).

Kadam A. (2013). Application of GIS in urban landuse changes in the PCMC (Pimpri Chinchwad Municipal Corporation) (Unpublished PhD Thesis. S.N.D.T. Women's University, Mumbai).

Kewalramani G. (2002). Land use changes in the peri-urban interface of Mumbai: a case study of the Vasai-Virar lowlands, managing the Urban Fringe of Indian Cities. Institute of Indian Geographer, University of Pune.

Kulshreshtha V., Maheshwari S. (2011). Blood bank management information system in India. International Journal of Engineering, 1(2).

Kulshreshtha V., Maheshwari S. (2012). Benefits of management information system in blood bank. International Journal of Engineering and Science, 1(12), 5-7.

Manonmani R., Suganya G. (2010). Remote sensing and GIS application in change detection study in urban zone using multitemporal satellite. International J. of Geomatics and Geosciences, 1(1).

Nagarale V.R., Ohal A.S. (2017). Changing urban landuse in Pune Municipal Corporation, Pune, Maharashtra: 1981-2011. Maharashtra Bhugolshastra Parishad, 34(2), 1-8.

Prasad V.K. et al. (2001). Measuring urban sprawl: a case study of Hyderabad. Available at: https://www. geospatialworld.net/article/measuring-urban-sprawl-a-case-study-of-hyderabad/

Shekhar S. (2005). Monitoring urban sprawl of Pune by using remote sensing and GIS technique (PhD Thesis. University of Pune).

Sokhi B.S., Rashid S.M. (Eds.) (1999). Remote sensing of urban environment. Manak Publications Ltd., Delhi.

Sudhira H.S. et al. (2003). Urban growth analysis using spatial and temporal data. J. Indian Soc. Remote Sensing, 31(4).

Walsh S.J. et al. (2001). A multiscale Analysis of LULC and NDVI variation in Nang Rong district, Northeast Thailand. Agriculture, Ecosystems and Environment, 85, 47-64.

Zope R.P. (2013). The planning strategies for urban land use pattern: a case study of Pune City, India. International Journal of Innovative Research in Science and Engineering and Technology, 2(7).

\section{Acknowledgement:}

The present study has been carried out with my student Ms. Anuradha Ohal, who is working for doctoral dissertation. I acknowledge her sincere efforts to collect information as well as data processing.

\section{Article history:}

Received: 25 May 2018

Revised: 06 August 2018

Accepted: 22 September 2018

\section{For citation:}

Nagarale V. (2018). Geographical assessment of urban utilities in Pune Municipal Corporation region with changing urban population. RUDN Journal of Economics, 26(3), 506-519. DOI: 10.22363/2313-2329-2018-26-3-506-519

\section{Bio Note:}

Nagarale Virendra, Professor and Head Department of Geography, S.N.D.T. Women's University Pune Campus. Contact information: e-mail: drnagarale@gmail.com 


\title{
Географическая оценка городских коммунальных услуг в муниципалитете Пуна в условиях изменения численности городского населения
}

\author{
В. Нагарале \\ СНДТ Женский университет \\ Индия, Пуна, 411038, Карве-роуд, Махарши Карве Видьявихар
}

Быстрый рост городской территории и чрезвычайный рост населения являются самыми драматическими явлениями, связанными с урбанизацией. Быстрый и беспорядочный рост городов и увеличение населения приводят к различным неблагоприятным последствиям для городской среды. В Индии крупные мегаполисы уже насыщены из-за крупномасштабной иммиграции населения. Городские центры и столичные города растут беспорядочно во всех направлениях без надлежащего планирования. Пуна - восьмой по величине город в Индии по численности населения и ВВП, что обусловлено быстрой урбанизацией. Численность населения Пуны вырастет с 5,5 до 7,7 млн чел. к 2030 г. и создаст серьезную нагрузку на основную городскую инфраструктуру. Город Пуна находится между $18^{\circ} 25^{\prime}$ и $18^{\circ} 37^{\prime}$ с. ш. и $73^{\circ} 44^{\prime}$ до $73^{\circ}$

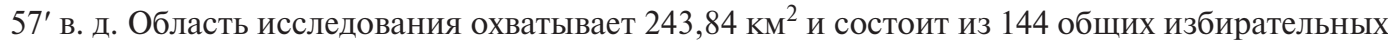
палат. По данным на 2011 г., муниципалитет Пуна состоит из 14 административных подразделений с населением 3,12 млн жителей. В настоящем исследовании учитывается влияние демографических изменений на функционирование коммунальных служб города. Неравномерное распределение различных коммунальных услуг приводит к проблемам в управлении и планировании. В статье рассматриваются центры e-Suvidha и круглосуточные медицинские магазины. В Пуне 88 центров e-Suvidha и 124 медицинских магазина, доступных круглосуточно. В административном районе Хадапсар сконцентрирована большая часть населения муниципалитета Пуна. В 2011 г. эта палата насчитывала 3,24 млн чел. Здесь находится $16 \%$ центров Maha e-Suvidha, 12 \% медицинских магазинов, которые открыты 24 часа. Если сравнить эти услуги с общей численностью населения, заметно, что соотношение количества населения и доступных коммунальных услуг неравномерно и не учитывает различные географические параметры.

Ключевые слова: урбанизация, городские услуги, муниципалитет Пуна, ВВП

\section{История статьи:}

Дата поступления в редакцию: 25 мая 2018

Дата проверки: 06 августа 2018

Дата принятия к печати: 22 сентября 2018

\section{Для цитирования:}

Нагарале В. Географическая оценка городских коммунальных услуг в муниципалитете Пуна в условиях изменения численности городского населения // Вестник Российского университета дружбы народов. Серия: Экономика. 2018. Т. 26. № 3. С. 506-519. DOI: 10.22363/2313-2329-2018-26-3-506-519

\section{Сведения об авторе:}

Нагарале Вирендра, профессор, руководитель географического факультета СНДТ Женского университета Пуны, Индия. Контактная информация: e-mail: drnagarale@gmail.com 